\title{
The Rules of the Game and the Morality of Efficient Breach
}

\section{Gregory Klass*}

Because contractual obligations result from acts of agreement, every contract has an origin story-a story about what the parties did to change their legal situation, to enter into a contract. Theories of contract law, in turn, often tell stylized versions of such stories. These theory stories tell us about the character of the parties, what they want from their transaction, how they arrive at an agreement, and how the law figures into their relationship.

The theory of efficient breach is no exception. It depicts contracting parties as self-interested rational utility seekers engaged in a value creating exchange, who are highly sensitive to legal incentives and want to maximize the value of the transaction, which they divide according to their relative bargaining power. The theory then tells stories about what can happen when performance turns out to be inefficient, whether because the out-of-pocket costs of performing increase or because a better opportunity comes along. In one story, the parties attempt to negotiate a release. But because they have no one else to deal with and each wants only to maximize its own profit, they end up wasting resources agreeing on an exit price. In another story, one side realizes that its performance will be inefficient and is given a cheaply exercised option to avoid performing, by paying off the other side. The difference in transaction costs provides the stories' moral: it is better to structure remedies so that when one side's performance becomes inefficient it can breach and pay, rather than forcing it to negotiate a release. Thus the law's preference for expectation damages.

To say that the efficient breach theory tells stories is not to say that the theory is false. It is difficult to find a theory of contract law that does not include such narrative elements. If the theory of efficient breach is different, it is because it has a surprise ending. We might think that breach

\footnotetext{
* Agnes N. Williams Research Professor, Professor of Law, Georgetown University Law Center. I am grateful for comments I received on this article at the Georgetown Law Summer Workshop and the Yale-UCL Workshop on the Philosophy of Contract, and from helpful conversations and correspondence with Hanoch Dagan, Guillermo Garcia-Sanchez, Naomi Mezey, Claire Salinas and Jessica Silbert.
} 
is a wrong that contract law is designed to prevent or rectify. The efficient breach stories suggest that some breaches are good things, and that contract remedies are designed to encourage them.

Carol Rose observed over twenty-five years ago that the stories we tell about the law are not inert. "[T]he storyteller, by structuring the audience's experience and imagination, helps to turn her audience into a moral community." The efficient breach theory tells a story about the attitudes of contracting parties and the purposes of contract law. In doing so, it invites the audience to imagine a particular moral community, one in which the audience's naïve assumptions about promissory obligations and the law's attitude toward them do not apply. And by inviting legal actors to imagine that community, the theory can help bring it about. We use theory-stories not only to explain and understand the law, but also to guide our actions in relation to it.

In his 1939 film, La Règle du Jeu, or "The Rules of the Game," Jean Renoir imagines a society in which the familiar norms of marital fidelity do not apply. The film is set in the upper echelons of French society, which Renoir depicts as highly rule governed. There is a right and a wrong way to do everything from seat guests at dinner to hunt small game. But the rules of that society are not those of traditional or petit bourgeois morality. In particular, the film depicts marital infidelity as a transgression that is generally tolerated, so long as it is done in the correct way. Like the theory of efficient breach, La Règle du Jeu tells a story in which the conventional rules do not apply, but are replaced by a different and, it turns out, in some respects more demanding social morality.

This article identifies and explores multiple similarities between the theory of efficient breach and the story Renoir tells in La Règle du Jeu. Telling the stories together shines a light on often overlooked aspects of the theory of efficient breach. Many readers might not have seen the film. But its setting, characters and storyline employ familiar elements and are easily retold. In fact, the film's narrative is somewhat more accessible than some nuances of the efficient breach theory. Renoir's story can therefore be used to access underappreciated aspects of the theory.

At the risk of giving away my story's ending, I identify six points of contact between the film and the theory.

First, both depict a practice in which nominal transgressions of the rules are widely tolerated. In the film, marital infidelity is generally expected and accepted; in the theory, breach of contract is sometimes desirable.

Second, in both the film and the theory, because participants in the practice understand that those transgressions are tolerated, participants do not wrong one another in committing them. Everyone understands that

1. Carol M. Rose, Property as Storytelling: Perspectives from Game Theory, Narrative Theory, Feminist Theory, 2 YALE J. L. \& HUMAN. 37, 55 (1990); see also Robin West, Economic Man and Literary Woman: One Contrast, 39 MERCER L. REV. 867 (1988). 
such actions are a part of the game they are playing. This common understanding belies naïve moral criticisms of the efficient breach theory as encouraging the moral wrong of breaking a promise.

Third, it nonetheless remains possible to identify correct and incorrect ways to commit those transgressions. The film depicts a practice of marital infidelity governed by rules of discretion and detachment. A fully elaborated theory of efficient breach requires of the nonperforming party transparency and responsibility. Although the rules are different, in both cases nominally transgressive behavior remains rule governed.

Fourth, violations of those deeper rules are not priced but punished. In the film, characters who violate the rules of infidelity are banished from the society. A fully articulated theory of efficient breach recommends penalties or other supercompensatory remedies for breaching parties who refuse to pay damages or otherwise obstruct their recovery - a point that both courts and theorists too often overlook.

Fifth, even if participants in the practice do not wrong one another when they commit nominal violations, it remains possible to inquire into the moral value of the practice itself. Renoir depicts a society governed by rules, including the rules of marital infidelity, that work to prevent authentic forms of romantic love. Similarly, a practice of efficient breach might result in a form of sociability that we do not find valuable. In both cases, however, the question cannot be answered in the abstract. The value of any given social practice depends on who the participants are and the social context in which the practice occurs.

Finally, one should worry about the effects of such practices on those who do not understand or choose not to participate in them. In the film this point is illustrated by two characters, each of whom wants more traditional or authentic relationships than the practice of marital infidelity permits, and each of whom suffers as a result. The risk with respect to efficient breach is realized when nonsophisticates enter into transactions not understanding that the other side intends to breach if efficient.

The last three points reveal features of the efficient breach theory that are too often overlooked or underappreciated. The theory is not only compatible with but recommends punishing some contractual wrongs. Even if sophisticated parties are playing the game of efficient breach, we should ask about the moral value of the attitudes and relationships that the theory engenders. And we should worry about extending the theory beyond its premises, and especially to contracts involving parties who are not playing the game of efficient breach.

My use of La Règle du Jeu to explore the theory of efficient breach is somewhat different from other approaches to law and literature. I am neither looking for the law's appearances in the film (almost nowhere), nor applying the methods of literary interpretation or film criticism to 
theories of efficient breach. ${ }^{2}$ Instead I am using elements of Renoir's story in La Règle du Jeu to explain facets of the efficient breach theory. I see three reasons to explore the perhaps surprising parallels between the film and the theory.

First, the commonly told story of efficient breach is too simple along several dimensions. La Règle du Jeu, which also depicts a social practice that tolerates and even celebrates nominal transgressions, points the way toward a more complete account of efficient breaches.

Second, the film also points the way to a more complete account of the theory's moral implications. ${ }^{3}$ Legal theory commonly works by simplifying the world; literature and film commonly emphasize complexity. The standard story of efficient breach has an Aesopian structure: familiar characters engage in a stylized interaction to bring home a relatively simple moral. Renoir's tells a more layered story in $L a$ Règle du Jeu. The film does not have a single protagonist, but multiple, complex characters who interact and impact one another in various ways. The large cast and the film's narrative arc allow Renoir to depict a social practice that means different things to different people at different times. I argue that social meaning, and moral value, of the theory of efficient breach is similarly complex- $\mathrm{a}$ fact that simple efficient breach stories do not capture, and which both the theory's proponents and its critics too often ignore.

Finally, that the film and the theory, properly understood, share these structural features is itself an interesting and important fact. Law is in significant respects autonomous. But it is a social practice like others. The parallels between the film and the theory of efficient breach are striking. That said, perhaps we should not be so surprised that the twists and turns of a legal theory finds an analog in the depiction of another highly rulegoverned set of social relationships.

Part 1 of this article briefly introduces La Règle $d u$ Jeu and its characters. Part 2 provides an introduction to the theory of efficient breach and draws parallels to the attitude toward marital infidelity depicted in the film. Part 3 dives deeper into the film and the theory, arguing that the tolerated transgressions in both nonetheless remain highly rule-governed, and that the theory of efficient breach in particular leaves room for penalizing violations of its internal morality. Part 4 steps outside of the efficient breach theory and argues that Renoir's critical attitude towards the society the film depicts suggests two nonstandard moral criticisms of the theory of efficient breach.

Before jumping into the analysis, a few methodological comments. The first concerns my use of the film. I do not pretend to present a complete

2. See Peter Brooks, Literature as Law's Other, 22 Yale J. L. \& Human, 349, 350 (2010) (identifying various approaches to law and literature).

3. I'm grateful to Jessica Silbey for helping me see this point. 
theory of La Règle du Jeu. Like many great works of art, the film functions on multiple levels and has more than one message. My aim is to plunder it to say something interesting about the theory of efficient breach. Nor do I aim at completeness in even that. There is yet more one might say about the connections between the film and the theory. I largely ignore, for example, the subject of gender. Carol Rose has argued that prisoners' dilemma stories, which employ many of the same assumptions of the efficient breach theory, are deeply gendered. ${ }^{4}$ So too is the society depicted in the film, providing yet another interesting point of potential comparison. If I do not pursue those lines of analysis here, it is because I want to highlight other underappreciated aspects of the efficient breach theory. As usual, there is more one might say.

Second, readers might wonder why I do not address the structural similarities between marriage and contract. Given that marriages involve an exchange of vows, might we say that marital infidelity as depicted in the film is itself a form of efficient breach? I think not. Although spouses voluntarily undertake their marital obligations, traditionally the content of those obligations is not a matter of agreement. The marital obligations, nominal and actual, that the film depicts are not chosen obligations in the way contract duties are. They are imposed by society. This difference between marriage and contract is more significant than the similarities between the two.

The final comment concerns this article's attitude toward the theory of efficient breach. My question is not whether that story, or the theory, is correct. It is, rather, about the moral community it depicts. I therefore devote relatively few words to whether or not the efficient breach theory succeeds. There are reasons to doubt both the model that the theory employs and whether the theory succeeds within that model. I have discussed the theory's debilities in considerable detail elsewhere. ${ }^{5}$ Robert Scott, who with Charles Goetz coined the term "efficient breach," now believes that the theory describes very few breaches.

It was a nice try but, in fact, the theory does not fit the data well. There are very few examples in the case law of an efficient breach in which one party has chosen not to perform and instead offered to pay the expectation damages that are subsequently assessed by the court. ${ }^{6}$

Despite the theory's defects, I would invite the skeptical reader to suspend her disbelief. Over the past four decades, the theory of efficient breach has become an important part of the story US scholars and jurists tell about the remedies for breach of contract. Regardless of whether the theory is

4. Carol Rose, Game Stories, 22 YALE J.L. \& HuMAN. 369 (2010).

5. Gregory Klass, Efficient Breach, in PHILOSOPHICAL FOUNDATIONS OF CONTRACT LAW 362 (Gregory Klass, George Letsas \& Prince Saprai, eds., 2014).

6. Robert E. Scott, Contract Law and the Shading Problem, 99 MARQ. L. REV. 1, 10-11 (2015). 
successful or descriptively correct, it is today part of the background understanding of contract remedies. ${ }^{7}$ It makes an appearance in the Restatement (Second) of Contracts, ${ }^{8}$ and several state high courts and federal Courts of Appeals have expressed official approval of the theory. ${ }^{9}$ As such, it is worth considering it on its own terms.

\section{JEAN RENOIR'S $L A R E$ REGLE DU JEU}

The history of La Règle du Jeu is a strange one. ${ }^{10}$ When Renoir made the film in 1939, he was already a well-known director, having produced among other films Boudu sauvé des eaux (1932, later remade as Down and Out in Beverly Hills (1986)), La Grande Illusion (1937), and La Bête Humaine (1938), all of which were popular and critical successes. $L a$ Règle du Jeu was a popular disaster. As a result, the original one-hundred and thirteen minute film was cut to ninety and then eighty-five minutes. The Nazis subsequently blacklisted the film, and in 1942 an Allied bombing raid destroyed the negatives and the only complete cut. The version commonly available today, which I discuss, is a 1958 reconstruction. Two film enthusiasts created it with Renoir's help using remaining prints, negatives and found fragments.

La Règle du Jeu follows the structure of a classic French comedy, with multiple characters involved in complex and overlapping romantic entanglements. ${ }^{11}$ The action takes place in 1939, the first twenty minutes in Paris and the remaining hour and twenty minutes at La Colinière, a

7. A search run on January 31,2016 of all US judicial opinions in Westlaw for the term "efficient breach" and excluding cases in which Judge Posner was on the panel returned one-hundred and eightythree results. See generally Jeffrey L. Harrison, The Influence of Law and Economics Scholarship on Contract Law: Impressions Twenty-Five Years Later, 68 N.Y.U. ANN. SURV. AM. L. 1, 2 (2012) (concluding from an empirical study of judicial opinions that "it is clear that law and economics scholarship, at least in the context of contract law, has affected the vocabulary and reasoning of courts").

8. Chapter 16: Introductory Note, in RESTATEMENT (SECOND) OF CONTRACTS 99-100 (1983).

9. See, e.g., United States v. Blankenship, 382 F.3d 1110, 1133-34 (11th Cir. 2004) ("It is not illegal for a party to breach a contract; a contract gives a party two equally viable options (perform or pay compensation), between which it is generally at liberty to choose. A "promise" contained in a contract is ... a grant of a legal right to the other party to either enjoy performance or receive damages. Indeed, the whole notion of "efficient breach" is that a party should abrogate its contractual responsibilities if a more profitable opportunity comes along."); Patton v. Mid-Continent Sys., Inc., 841 F. 2d 742, 750 (7th Cir. 1988) ("[T] he breach did little, perhaps no, damage to either plaintiff, and it is therefore quite possible that it was an efficient breach in the sense that it increased MidContinent's profits by more than it caused anyone losses. If so, the refusal to rectify the breach, while deliberate, would not justify an award of punitive damages."); Bhole, Inc. v. Shore Investments, Inc., 67 A.3d 444, 453 n.39. (Del. 2013) ("Delaware recognizes this principle of efficient breach."); Grynberg v. Citation Oil \& Gás Corp., 573 N.W.2d 493, 500 (S.D. 1997) ("[O]ur free market system allows economically efficient breaches of contract."); Story v. City of Bozeman, 791 P.2d 767, 774 (Mont. 1990) ("Parties have traditionally been free to breach their contract and pay contract damages whenever performance was not economically efficient."); L.L. Cole \& Son, Inc. v. Hickman, 665 S.W.2d 278, 280 (Ark. 1984) ("The law has long recognized the view that a contracting party has the option to breach a contract and pay damages if it is more efficient to do so.").

10. See generally Historical Note, in RULES OF THE GAME: A FILM BY JEAN RENOIR 19-21 (J. McGrath \& Maureen Teitelbaum trans., 1970) [hereinafter "SCREENPLAY"].

11. See AleXander Sesonske, JeAn RENOIR: THE FrenCh FILMS, 1924-1939, 391-92 (1980). 
country estate. The characters can be divided into two groups: those who belong to the Parisian upper class and those who belong to the servant class working for them. The primary characters in each can be organized according to their relationships to a focal marriage in that group.

Among the upper-class characters, the focal marriage is that between Robert and Christine de la Cheyniest. Robert is wealthy marquis and owns La Colinière. His wife Christine grew up in Salzburg, the daughter of a famous conductor. There are three other principal upper-class characters, each of whom has a romantic relationship with either Robert or Christine. Geneviève de Marras is a modern, sophisticated single woman and has maintained an ongoing affair with Robert since before his marriage. André Jurieux is a handsome young pilot who in the opening scene has just completed a solo flight across the Atlantic and is madly in love with Christine. Octave-played by Renoir-is a failed conductor, André's close friend, and an old friend of Christine's, having studied with her father. There is a suggestion that Octave survives at least in part through Robert's generosity. Late in the film Octave professes his romantic love for Christine, and she for him.

Among the servants, the focal marriage is between Lisette and Edouard Schumacher. Lisette serves as Chistine's chambermaid and therefore resides mostly in Paris. Her husband, whom everyone refers to with the Gallicized "Shumaché," is the gamekeeper at La Colinière. During the film the audience sees Lisette in two affairs. The first is a lighthearted and flirtatious relationship with Octave, acted out in Paris and before Octave's romantic encounter with Christine. Lisette's second affair is with Marceau, a poacher whom Robert hires, much to Schumacher's consternation, as a low-level servant at La Colinière.

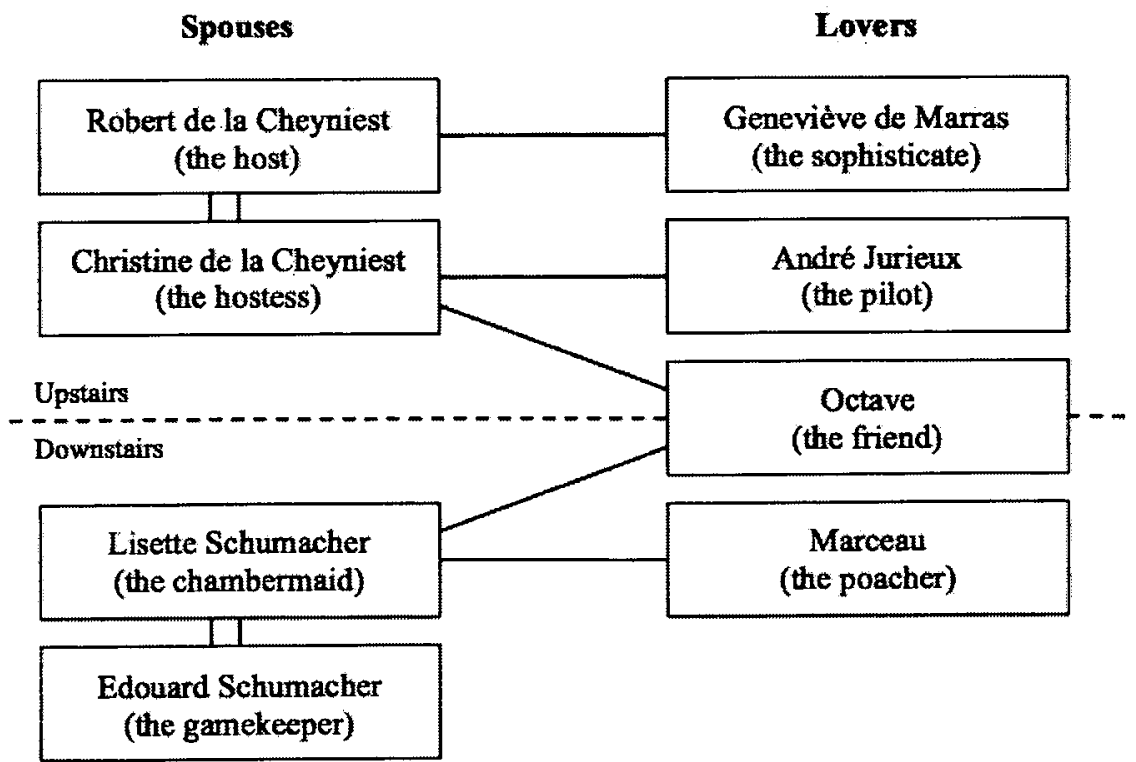


La Règle du Jeu addresses many themes, including the mechanics of social class, the feel on the eve of the Second World War, the violence of war itself, and its characters' beliefs, motives and desires. Here I focus on one: the rules governing marriage and infidelity in upper-class pre-war Parisian society, as depicted in the film.

In that society, infidelity is a common and tolerated transgression. In the first scene, André-who has just landed in a field outside Paris- declares over the radio that he has flown across the Atlantic out of love for a woman. The audience immediately learns that she is the married Christine, and the next scene finds Christine and Lisette discussing Lisette's many lovers. Then, after a brief interchange between Christine and Robert, in which Robert acknowledges that André was speaking of Christine, the audience learns of Robert's relationship with Geneviève. In her first scene-still in the first ten minutes of the film-Geneviève quotes Chamfort: "Love, such as it exists in high society, is merely an exchange of whims and the contact of skins." 12

At the same time, marital infidelity is tolerated only within certain bounds. Infidelity is a rule-governed transgression. Extrapolating from the film as a whole, the two most important rules are that parties keep the affair discrete and that they remain emotionally detached. The film's plot is driven forward by violations those rules. Those violations all involve the two Austrian characters, Christine and Schumacher, each of whom misunderstands or rejects the local rules of infidelity.

Christine's desire for authentic attachments and honesty are apparent from her first scene, in which she suggests to Lisette that genuine friendship with a man might be possible. Lisette, who is French and understands the rules, replies, "You might as well talk of the moon in broad daylight." 13 A short while later, talking to Robert about their affair, Geneviève diagnoses Christine's attitude:

Christine has remained very much a product of her country. A Parisienne would understand. Not her! ... If she learns the truth, it will not be because of our liaison that she'll be upset with you, it will be because of your having lied to her from the time you got married. ${ }^{14}$

As the film progresses, one man after another in Christine's life breaks the rules of infidelity out of love for her. In the opening scene, André violates the rule of discretion when he publicly declares his love for Christine in a way that Robert and the others immediately understand, for which Octave upbraids him. Shortly after, Robert discusses the matter with Christine,

12. SCREENPLAY, supra note 10, at 37-38. " $L$ 'amour, tel qu'il existe dans la société, est l'échange de deux fantaisies et le contact de deux épidermes." I have slightly revised the screenplay's translation. See Deke Dusinberre, Limits of Translation, N.Y. REV. BOOKS (Sept. 24, 1992), available at: http://www.nybooks.com/articles/archives/1992/sep/24/limits-of-translation/.

13. Id. at 32 .

14. Id. at 39 . 
who thanks him for his honesty. Christine's authenticity and naïveté then cause Robert to resolve to end his longstanding affair with Geneviève-a resolution he is too weak to follow through on, but which begins to disrupt their otherwise functioning affair. Later in the film, Octave's love for Christine cause him to send Andre out to meet her, leading to the film's tragic ending. And then there are Christine's own actions. After finally discovering Robert's affair with Geneviève, for example, she decides to take as a lover a relatively minor and unsympathetic character, SaintAubin. But she does so in such a brazen and clumsy way that both Robert and André see what is happening, resulting in a series of physical altercations and then general chaos.

If the upstairs plot is driven largely by Christine and her lovers' breaches of the rules of infidelity, the plot downstairs is driven by Schumacher's inability to recognize that infidelity is a transgression to be tolerated. Schumacher consistently acts on the belief that his marriage to Lisette is governed by the traditional, public rules of marriage, including that a wife should live with her husband and remain faithful to him. But Lisette is an enthusiastic player at infidelity. In her first scene, she explains to Christine that she has affairs, including one with Octave, and suggests that she does not take any of it seriously. Schumacher, who lives at La Colinière while Lisette is in Paris, is oblivious to all this. His simple adherence to public conventions and rules serves as comic fodder in much of the film. In one of Schumacher's first scenes, he laments to his underlings that it is impossible to control the rabbit population, and then in the next breath complains that Marceau has again been poaching them. Schumacher is generally blind to the occasional advantages of transgression. After Robert hires Marceau to serve in the house, the poacher enters into a lighthearted affair with Lisette, which Schumacher, with his rigid adherence to the rules, cannot understand or accept. The remainder of the downstairs plot is driven by Schumacher's ignorance of, then outrage at, his wife's infidelity, culminating in an extended comic chase through the house, during which Schumacher empties his pistol in an attempt to kill Marceau.

The structure of La Règle du Jeu therefore exhibits a bilateral symmetry. The plot and relationships downstairs are something like mirror images of the plot and relationships upstairs. One partner to each of the focal marriages understands and plays by the rules of infidelity. Upstairs this is Robert, downstairs it is Lisette. Each is married to a foreigner who does not play by those rules. Robert is married to Christine, who acts out of love and values honesty, both of which run contrary to the local rules of infidelity. Lisette is married to Schumacher, who is attached to the public and petit bourgeois rules of marriage, which forbid infidelity altogether. The plot is driven by Christine's failure to follow the rules of infidelity and by Schumacher's failure to understand that infidelity is a transgression to be tolerated. 
This then is the basic structure of La Règle du Jeu. The full plot and cast of characters are complex and convoluted enough to preclude easy summary. Although I will describe many other pieces of the film, it will help the discussion that follows to reveal its ending. After numerous conflicts and adventures produced by the many extramarital liaisons, four characters are effectively banished from the society at La Colinière. After the chase through the mansion, Robert dismisses Schumacher from his service, and then also Marceau. Having together left the house, Schumacher and Marceau believe they see Octave together with Lisette. Although Octave did once have an affair with Lisette, in fact they are seeing Octave professing his love to Christine. Schumacher and Marceau go to get Schumacher's gun. Octave goes inside the house, is convinced by Lisette that he cannot support Christine, and out of love for Christine allows André to take his place. Schumacher and Marceau return. Schumacher, now under the double misperception that André is Octave and Christine is Lisette, shoots and kills André. Octave is crushed, not in the least because of his role in André's death. As dawn approaches, Octave departs from La Colinière on foot to make his way back to Paris. The net result is that all three male lovers plus Schumacher leave La Colinière, one in a coffin.

In the final scene, Robert explains to the remaining guests that André's shooting was a "deplorable accident ... My keeper Schumacher thought he saw a poacher, and he fired, since that is his duty." 15 Saint-Aubin, who has played a minor role in the debacle, comments that this is a new definition of the word "accident," to which a senior gentleman, referred to as "the General," replies: "No, no, no, no, no! La Chesnaye does not lack class, and that is a rare thing, these days . . , believe me, a rare thing!"16

\section{EFFICIENT BREACH}

One need not go all the way to French cinema to illustrate the idea that rule breaking is sometimes acceptable. David and Daniel Luban observe that many baseball players and fans consider some forms of cheating permissible, and even part of the "fabric of the game." 17 Fans appreciate the pitcher who can get away with scuffing the ball or smearing a bit of Vaseline on it. They quote pitcher and manager George Bamberger:

There are rules, and there are consequences if you break them. If you are a pro, then you often don't decide whether to cheat based

15. Id. at $\mathbf{1 6 8}$

16. Id.

17. David Luban \& Daniel Luban, Cheating in Baseball, in THE CAMBRIDGE COMPANION TO Baseball 185, 186 (Leonard Cassuto \& Stephen Partridge eds., 2011). Another example is the practice of taking a dive in soccer. See Jeré Longman, Routine Ruse in Men's Soccer Tumbles Into Women's World Cup, N.Y. TIMES, July 11, 2011, at A1. 
on if it's "right or wrong." You base it on whether or not you can get away with it, and what the penalty might be. ${ }^{18}$

Bamberger's attitude here is akin to that of Holmes's heuristic bad man, "who cares only for the material consequences which [knowledge of the law] enables him to predict, not as a good one, who finds his reasons for conduct, whether inside the law or outside of it, in the vaguer sanctions of conscience." "The art of cheating on this picture is the taking of calculated risks. The sophisticated cheater weighs the possible gains of a transgression against the consequences should she be caught, and transgresses only when it is a good bet.

The theory of efficient breach tells a similar story about the law's attitude towards some breaches of contract. ${ }^{20}$ Proponents of the theory treat efficient breach as not only a tolerable transgression, but one the law should encourage. Expectation damages are designed to give promisors a reason to breach when nonperformance will create more value than will performance. Robert Birmingham, who first articulated the theory in print, explained the idea as follows:

Repudiation of the obligations should be encouraged where the promisor is able to profit from his default after placing his promisee in as good a position as he would have occupied had performance been rendered. Failure to honor an agreement under these circumstances is a movement toward Pareto optimality.... To penalize such adjustments through overcompensation of the innocent party is to discourage efficient allocation of resources. ${ }^{21}$

A breach is efficient when the net gains from nonperformance exceed the net gains from performance, that is, when performing the contract would reduce overall social welfare. Expectation damages encourage efficient breach by allowing the breaching promisor to keep the gains from nonperformance. Knowing that she will be required to put the nonbreaching party in the position he would have occupied had she performed, the promisor will choose to breach when and only when the total gains from nonperformance exceed the total gains of performance. According to the theory of efficient breach, this is a good thing. As Birmingham says, "repudiation of the agreement should be encouraged where gain to the [breaching party] will exceed loss to the [non-breaching party]."22 Or Posner two years later: "If [the cost of performance] is greater than the gain to the other party from completion, it is clear that

18. Id. (quoting THOMAS BOSWELL, HOW LIFE IMITATES THE WORLD SERIES: AN INQUIRY INTO THE GAME 198 (1982)).

19. Oliver W. Holmes, The Path of the Law, 10 HaRV. L. REV. 457 (1897), reprinted in 110 HARV. L. REV. 991, 992 (1996-1997).

20. For a more thorough account of the theory of efficient breach, see Klass, supra note 5.

21. Robert L. Birmingham, Breach of Contract, Damage Measures, and Economic Efficiency, 24 RUTGERS L. REV, 273, 284 (1970).

22. Id. at $288-89$. 
commission of the breach would be value maximizing and should be encouraged." ${ }^{23}$ Or Goetz and Scott a few years after that: "The modern law of contract damages is based on the premise that a contractual obligation is not necessarily an obligation to perform, but rather an obligation to choose between performance and compensatory damages."24

These and other first-generation social-welfare theories of efficient breach were not entirely successful. ${ }^{25}$ Here are two reasons, each internal to the model. First, in some contracts specific performance, disgorgement or even punitive damages might, when performance becomes inefficient, result in a negotiated release, perhaps with lower overall transaction costs. Second, the theory's exclusive focus on the perform-breach decision neglects the incentives remedies create elsewhere in the transaction, such as the promisee's incentives to rely on performance - incentives that expectation damages might get wrong. More generally, the theory's descriptive accuracy depends on empirical facts that are difficult to observe and might differ across transactions. Hard empirical questions include how much parties know about one another, the costs and effectiveness of enforcement, the costs of bargaining for a release, and the influence of nonlegal norms and practices. Without knowing those and other facts, it is difficult to say which remedy maximizes overall welfare.

Despite these complications, the analysis that follows assumes that the efficient breach theory could hold true in a significant number of transactions. I am interested not in the theory's accuracy, but in the moral and legal implications of the story it tells. For those purposes, it is enough that the efficient breach theory could describe many transactions.

The early social-welfare efficient breach theorists treated contract remedies as if they were similar to remedies elsewhere in the law. There are, however, two important differences, which together form the basis of a more nuanced theory of efficient breach. First, unlike, say, the tortfeasor and tort victim, parties to a contract have the opportunity to agree in advance on the legal rules that will govern their subsequent interactions. Those rules include the remedy for breach. If parties are given the power to choose the remedy, the design question is not simply what remedy, but

23. RiCHARD A. POSNER, ECONOMIC ANALYSIS OF THE LAW 57 (1972).

24. Charles J. Goetz \& Robert E. Scott, Liquidated Damages, Penalties and the Just Compensation Principle: Some Notes on an Enforcement Model and a Theory of Efficient Breach, 77 COLUM. L. REV. 554, 558 (1977).

25. See Klass, supra note 5 at $370-79$. A more complete list of internal problems with the simple theory is as follows:

It fails to recognize that some breaches are not only inefficient, but opportunistic. It does not provide a defense of expectation damages as against other possibly equally efficient remedies. It focuses on the single perform-or-breach decision, when in fact remedial rules provide incentives to act more or less efficiently across the whole of a transaction. And it ignores other functions remedies serve, such as risk allocation and signaling. Id. at 370 . 
what default remedy and how to tell when parties have contracted around it.

Second, because contracts govern exchange transactions, the remedy can affect the price or other terms a party receives. In a competitive market, for example, a remedy that costs the seller more-say specific performance rather than expectation damages-will result in a higher price for the buyer. This price effect entails in the model that if a remedy increases the overall gains of trade, both parties benefit, either ex ante in the terms they receive or ex post by reaping the benefits of efficient performance decisions. Parties themselves therefore want remedies that increase the overall gains of trade, which is to say efficient remedies.

Later efficient breach theorists put these two observations together to make a new claim: Because expectation damages are often efficient, they are the remedy most parties would choose. Expectation damages are therefore the right default. Setting the default at the remedy most parties would choose saves those parties the transaction costs of specifying an alternative, and gets most parties the remedy they prefer. Whereas the early efficient breach theorists argued that expectation damages and efficient breach are desirable because they increase overall social welfare, later theorists argue that they are the rules sophisticated parties choose to play by - which can also be an indicator of social welfare.

The choice-based efficient breach story also suffers from complications. ${ }^{26}$ Like the simple social-welfare theory, it assumes empirical facts that are difficult to observe. Furthermore, if sophisticated parties are the ones who prefer expectation damages, they are also the ones with the knowledge and resources to contract for that remedy. Perhaps the default should be set to match the expectations of nonsophisticates. I again want to bracket such issues. I am not much interested in the correct default, or even which remedy most parties do or should prefer. For my purposes, it is enough that some parties might want to treat their contractual arrangements in the way the efficient breach theory describes. Again, I am interested more in the moral quality of the story that the theory tells than its accuracy.

With choice-based efficient breach theory we arrive at an account of contractual relationships and obligations very similar to Renoir's depiction of marital relationships and obligations in La Règle $d u \mathrm{Jeu}$. In the society depicted in the film, though marriage nominally imposes an obligation of fidelity, that obligation is widely understood to be a duty one need not keep. When an opportunity for an affair presents itself, it is not morally wrong to take it. According to the efficient breach theory, although many contracts are written as if any failure to perform is a breach, sophisticated parties enter into them expecting and even tolerating some types of

26. See id. at $384-86$. 
nonperformance. Thus Daniel Markovits and Alan Schwartz argue that contracts between sophisticated parties are best interpreted as promises to perform or pay, or as they put it, the promisee agrees to give the promisor a choice between performing the contract's "action term" and making a transfer to the promisee in the amount of his expectation, "so that it is not a breach when the promisor exercises the choice in favor of paying money." 27 The option to (nominally) breach and pay "is as real, as much a product of the parties' actual intentions, as the promises that constitute the action and price terms." 28 Sophisticated parties are playing a game of efficient breach that results in gains of trade that benefit everyone.

From this perspective, moralists who object to the theory of efficient breach on the grounds that it encourages promise breaking are like the hapless Schumacher, Lisette's Austrian husband. The gamekeeper does not understand that his French wife and everyone else around him are playing a game of love, sex and infidelity that is not at all like the traditional, petit bourgeois institution of marriage he grew up with. As a result, Schumacher comes off as a simpleton, and even a buffoon. Just as his unthinking adherence to the rule against poaching prevents him from seeing that Marceau the poacher is in fact helping him control the rabbit population, Schumacher's unthinking adherence to the traditional rules of marriage prevents him from understanding that his wife and the rest of the cast around him are playing a very different, and perhaps more enjoyable game. While Schumacher remains in his jackboots and warden's uniform upright, uptight and unhappy, his French wife and Marceau the poacher enjoy the pleasures of flirtation, seduction and romance. Schumacher's offense at their pleasure comes from an inability to understand the rules of the society in which he lives.

Many moral criticisms of the theory of efficient breach suffer from a similar naiveté. ${ }^{29}$ Some contractual promises might be the equivalent of, in

27. Daniel Markovits \& Alan Schwartz, The Myth of Efficient Breach: New Defenses of the Expectation Interest, 97 VA. L. REV. 1939, 1976 (2011).

28. Id. at 1978 .

Steven Shavell provides a somewhat different analysis that reaches the same result. Shavell focuses on the unforeseen events that cause an efficient breach. He argues that if, at the time of contracting, the parties had considered the possibility of such events, they would have agreed to no duty to perform in those circumstances. The parties' failure to address those events is therefore a gap in their agreement, which should be filled by looking to what they would have agreed to had they thought about the possibility. By linking the parties' moral obligations to what they would have agreed to, Shavell can conclude that an efficient breach is not immoral. See Steven Shavell, Is Breach of Contract Immoral, 56 EMORY L.J. 439 (2006); Steven Shavell, Why Breach of Contract May Not Be Immoral Given the Incompleteness of Contracts, 107 MICH. L. REV. 1569 (2008).

Seana Shiffrin and I have each argued that there are reasons to doubt such interpretations of the content of contractual promises. See Gregory Klass, To Perform or Pay Damages, 98 VA. L. ReV. 143 (2012); Seana Valentine Shiffrin, Must I Mean What You Think I Should Have Said?, 98 VA. L. REV. 159 (2012). For more from Shiffrin on the interpretive question, see Seana Valentine Shiffrin, Could Breach of Contract Be Immoral, 107 MICH. L. REV. 1551, 1563-67 (2008).

29. See, e.g., Daniel Friedmann, The Efficient Breach Fallacy, 18 J. LEGAL STUD. 1, 14 (1989) ("The efficient breach theory is in fundamental conflict with a basic premise of both the common law and other Western legal systems, namely, that property (including contractual rights) is not to be taken 
schoolyard parlance, "cross your heart and hope to die." And in some contexts, such as a promise between friends or intimates, the promisor's choice to breach and pay damages might be morally offensive. But it is parochial to take these local features of some promissory practices as necessary truths about the duties that attach to exchange agreements. Agreements and agreement keeping are social institutions. And an agreement's content and moral force depend at least in part on what the parties say and expect, which in turn depend on the context in which they transact. If sophisticated parties benefit from a duty that permits efficient breaches, and if that is how the parties themselves understand the commitments they undertake, then what is the harm in structuring contract remedies to assist them in realizing those ends? Contracts between sophisticated parties occur in a social spaces in which nominal violations are not only permissible, but even expected and encouraged. They are, in a sense, not in fact breaches-though they trigger a legal duty to pay damages. So long as the players understand the rules of the game, why should they not be given the benefit of playing it?

\section{The Rules of the Game}

Let me return for a moment to my domestic example: baseball. Although David and Daniel Luban maintain that baseball fans treat some forms of cheating not only as permissible, but as part of the fabric of the game, they also distinguish between "good cheating" and "bad cheating." ${ }^{30}$ Some cheating is presumably wrongful because it is morally wrong and just happens to occur in the context of baseball. The bean ball-a pitch aimed at the batter's head - would be an example. But the Lubans make a stronger claim. Some cheating is bad because it violates the "natural law of baseball: a code designed to maintain the balance

and given to another without the owner's consent."); Daniel Freidmann, The Performance Interest in Contract Damages, 111 L.Q. REV. 628, 629 (1995) ("The essence of contract is performance.... This interest in getting the promised performance... is the only pure contractual interest."); Douglas Laycock, Holmes, Posner and Efficient Breach, in THE DEATH OF THE IRREPARABle INJURY Rule 245, 255 (1991) ("The law's preference for specific relief . . . rests on views of morality and justice that run deep in Western culture. A promise creates an entitlement that should be honored."); Richard O'Dair, Restitutionary Damages for Breach of Contract and the Theory of Efficient Breach: Some Reflections, 46 CURRENT LEGAL PROBS. 113, 119 (1993) ("If the conversion of chattels is not legitimated by the tender of their value by way of compensatory damages payment, why should a promisor be able to deprive a promisee of his contractual rights merely by proffering the appropriate sum by way of expectation damages?"); Seana Valentine Shiffrin, The Divergence of Contract and Promise, 120 HARV. L. REV. 708, 731 (2007) ("A virtuous agent cannot believe both that a promise can be binding even if a better opportunity comes along that competes with fulfilling the promise and that breach of contract, involving breach of promise, is, all things considered, morally justified merely because it leads to (even only marginally) greater economic welfare."); Shiffrin, Could Breach of Contract Be Immoral, supra note 28, at 1552 ("The efficient-breach rationale forwards a justification for a legal doctrine that consists in the claim that barring punitive damages would encourage and facilitate certain breaching behavior. But this behavior is condemned by morality. To the extent the law adopts and embodies this rationale, it thereby embraces and tries to encourage and facilitate immoral behavior.").

30. Luban \& Luban, supra note 17 at 188. 
between batter and pitcher, the basic balance that sets the entire texture of the game." ${ }^{31}$ Arguably in this category is the rule that a hitter may not peek behind to see how the catcher is setting up. When a hitter knows what pitch is going to come, it makes baseball a worse game. "The rules that matter are the rules that keep baseball as near to perfect as it can be. Breaking those rules is cheating; breaking the lesser rules is simply good dirty fun." ${ }^{32}$ If the Lubans are correct, one can distinguish between the virtuous and the nonvirtuous cheater in baseball. Though the virtuous cheater will be penalized when caught, his transgressions do not disrupt the fundamentals of the game. The nonvirtuous cheater, in distinction, threatens to undermine the game. His transgressions cannot be tolerated.

\section{A. Rules of Infidelity}

One finds a similar distinction in La Règle du Jeu. Although the film depicts a society in which the cognoscenti treat infidelity as a transgression to be tolerated and even enjoyed, it does not follow that anything goes-Cole Porter notwithstanding. The film depicts friendship, employer-servant relations, the relationship between a host and his guests, a hunt, and many other activities as governed by complex social rules. In a shockingly brutal scene, beaters drive a host of rabbits and pheasants out of the woods to be shot down by the guests. The scene is bookended by two exchanges. Before the serious killing begins, two minor characters engage in a dialog of exaggerated civility:

La Bruyere: Forgive me, Saint-Aubin, I was a little taken aback when I shot this pheasant. I thought it was coming over me, but really it's yours, absolutely ...

Saint-Aubin: No, no. When I shot it, it was beyond the little pine tree...

La Bruyere: I assure you not, dear boy, it was yours.

Saint-Aubin: Oh! You are too kind! $!^{33}$

Once the shooting is over, the same characters again invoke the rules, this time with childish anger:

Saint-Aubin: I say there, that pheasant, there, there, on the left ...

La Bruyere: Listen, Monsieur, this time it's mine, there can be no doubt about it.

Saint-Aubin: Ah! No. This time, it's mine. You're not going to poach every bird that comes over. The last time, you took one from right under my very nose and I didn't say a word. ${ }^{34}$

31. Id. (emphasis in original).

32. Id. at 195 .

33. SCREENPLAY, supra note 10 , at 86 .

34. Id. at 98 . 
The film depicts a world that is fully governed by rules. The characters know their social roles, never question the rules that govern those roles, and generally adhere to them.

There are rules governing infidelity as well. Although infidelity is a tolerated transgression, it is condoned only when done correctly. Early in the film, as the guests are arriving at La Colinière, an anonymous servant is taken aback when she learns that André is to be seated to Christine's right at the dinner table. "Oh! Well, she's wrong! I'm all for doing what I want in life, but conventions are conventions!" 35 Even downstairs it is understood that infidelity is only to be tolerated when done correctly.

The rules that govern infidelity in the film can be divided into two broad categories. The first comprises general rules that happen to also apply to those engaging in infidelity. After André and Christine decide to run away together, they find themselves disagreeing about whether they should wait to tell Robert.

André: I cannot after all run off with the wife of a gentleman who is receiving me at his home... who calls me his friend... to whom I give my hand... without at least giving him an explanation.

Christine: But since we love each other, André?... What can it matter?

André: Christine ... there are certain rules, after all! ${ }^{36}$

Though André is smitten with Christine, he remains a gentleman, and as such cannot violate the rules of friendship or neglect his duties as a guest.

More significant for my purposes are the rules specific to infidelity, which require discretion and detachment. The film depicts Robert and his lover Geneviève as the consummate players of the game of infidelity. Robert's affair with Geneviève predates his marriage to Christine. He has never been a faithful husband. But he has kept the affair hidden from his wife. Although Octave, Lisette and almost everyone else in the film knows of it, Christine does not discover the affair until midway through the film, when she spies Robert and Geneviève embracing. Nor do either Robert or Geneviève seem especially motivated by love. After telling Christine that he keeps no secrets from her, Robert is driven by guilt to break off the affair with Geneviève. When he attempts to do so, Geneviève describes her feelings toward him: "Believe me if you want to, Robert: I care for you. I don't know if it's love or the result of habit, but if you left me, I would be very unhappy and I do not want to be unhappy." Robert lamely agrees to continue the affair, and Geneviève observes, "Oh well, it's a good thing for me you're a weak man." ${ }^{37}$ The relationship is one of

37. Id. at 39 . 
convenience, habit, and mutual benefit. The rules of infidelity require dissimulation $^{38}$ and detachment. ${ }^{39}$ So long as Robert and Geneviève remain together, they understand and largely abide by them.

As I observed above, the film's plot is largely driven by violations of those rules. Upstairs the most significant transgressions are André's all too public and passionate devotion to Christine, Octave's true love for Christine, and Christine's own transparency, authenticity and emotional involvement. Downstairs the plot is driven by Schumacher's inability to understand the game of infidelity that his wife and Marceau the poacher are playing. In all these instances, the dramatic tension comes not from the cheating, but a failure to abide by the rules that govern cheating. The film depicts a world in which some rules are expected to be followed and some to be broken, and where rules of the latter type can be broken in the right way or in the wrong way.

\section{B. Rules of Efficient Breach}

Although rarely emphasized by its advocates, a fully articulated theory of efficient breach tells a similar story about the law of contracts.

The economic and instrumentalist approach that supports efficient breach does not entail that anything goes. The theory does not countenance, for example, wrongs at the time of formation such as duress and misrepresentation. Enforcing party choice advances welfare and enhances autonomy only when that choice is voluntary and knowing. Duress and misrepresentation are therefore transgressions that should not be tolerated.

Nor does the efficient breach theory celebrate all instances of nonperformance. The opportunistic breacher, who breaches only to take advantage of the other side's vulnerability and transfer gains to herself, does not increase the joint gains of trade but merely redistributes them. As such, she is not playing by the rules of the efficient breach game. Thus, Richard Posner recognized in the 1986 edition of his Economic Analysis of Law that "[i]f a promisor breaks his promise merely to take advantage of the vulnerability of the promisee ... we might as well throw the book at [him]. ${ }^{, 40}$ For the same reason, the theory supports a mandatory duty of

38. The social acceptability of lies appears in Robert and Christine's first scene together. After Robert says he understands her relationship with André, Christine thanks him, explaining, "A lie is a very heavy garment to carry around." Robert is dismissive. "A lie, you exaggerate." Id. at 36. Such dissimulation is a normal and accepted part of Robert's world.

39. A nice statement of the rule of detachment can be found in an exchange between André and Octave on the latter's penchant for affairs with servants. Although André does not play by the rules with Christine, as a member of the upper class he understands them. "But, old boy, despise them, take their money and then, from time to time, give them a few good slaps, you'll see how they adore you. But if you are unfortunate enough to show them that you love them ... you're done for!" Id. at 88 . (The dialog can be heard on the complete soundtrack of the original film, but is not in the reconstructed version.)

40. Richard A. Posner, ECONOMiC Analysis of LAW 105 (3d ed., 1986). 
good faith that fills the interstices of the parties' express agreement with a generic requirement that they not take unbargained-for advantage of one another. ${ }^{41}$ One party's willful attempt to exploit the other's misunderstanding of their contract, for example, "has no social product, and ... like theft it induces costly defensive expenditures, in the form of overelaborate disclaimers or investigations into the trustworthiness of a prospective contract partner, just as the prospect of theft induces expenditures on locks." 42

In addition, and more significantly for my purposes, the principles that support efficient breach also entail that there are right and wrong ways to efficiently breach a contract. In order to explain why, it is necessary to go a bit deeper into the efficient breach theory.

The argument for efficient breach turns on relative transaction costs. Efficient nonperformance can result either from a unilateral decision, made by one party acting in the shadow of the expectation remedy, or by a negotiated release, in which both sides agree to discharge the contract in the umbra of deterrence-based supercompensatory remedies or injunctive relief. ${ }^{43}$ The question is which reaches that outcome at a lower cost, thereby producing greater expected gains of trade for the parties to divide. The argument for using expectation damages to incentivize efficient breach is that when performance becomes inefficient, it is cheaper for one party to decide to breach and pay damages than it is for two parties, who are in a bilateral monopoly, to agree to an exit price.

Although the efficient breach argument turns on relative transaction costs, efficient breach theorists have not had much to say about how the law might reduce - or incentivize the parties to reduce - the costs of efficient breach decisions. ${ }^{44}$ Two costs of efficient breach are especially salient. The first is the cost to each party of knowing when breach is efficient, which requires knowing inter alia how much the other side stands to gain from performance. Richard Brooks has suggested that this cost sometimes recommends restructuring the incentives to give the unilateral performance decision to the party owed performance, rather than the party owing it. ${ }^{45}$ The second is the cost of ensuring that a breaching party pays the expectation damages she owes the nonbreaching party.

41. For an account of the duty of good faith along these lines, see Daniel Markovits, Good Faith As Contract's Core Value, in PHILOSOPHICAL Foundations of CONTRACT LAW, supra note 5, at 272.

42. Market Street Associates Ltd. Partnership v. Frey, 941 F.2d 588, 594 (7th Cir. 1991) (Posner, J.). Todd Rakoff argues that efficiency supports an even more robust duty of good faith, "imposing an obligation on one party without regard to motive in order to facilitate the other party's knowing performance." Todd D. Rakoff, Good Faith in Contact Performance: Market Street Associates Partnership v. Frey, 120 HARV. L. REV. 1187, 1196 (2007).

43. See Klass, supra note 25 at 372-73; see also Robert L. Birmingham, Damage Measures and Economic Rationality: The Geometry of Contract Law, 1969 DUKE L.J. 49, 70; Alan Schwartz, The Case for Specific Performance, 89 YALE L.J. 271 (1979).

44. The discussion in the next few paragraphs draws on Gregory Klass, Contracting for Cooperation in Recovery, 117 YALE L.J. 2 (2007).

45. Richard R.W. Brooks, The Efficient Performance Hypothesis, 116 YALE L.J. 568 (2006). 
These costs depend in large part on the behavior of the party in breach. They thereby provide markers of, in efficiency terms, right and wrong ways to efficiently beach a contract.

Once a party has decided to efficiently breach, she has a choice. She might volunteer to pay damages, or she might sit back and wait for the nonbreaching party to sue. The first option reduces the costs of the nonbreaching party's recovery; the second increases those costs. This is not the only way a breaching party might affect the costs of recovery. If breach is not easily observable, a breaching party can choose to inform the other side of her breach, to remain silent about it, or she might attempt to hide the breach. Before breach, a party might have a choice between keeping records of her performance, not keeping such records, or falsifying records. After breach, the breaching party might attempt to prevent or delay a lawsuit by providing false assurances that performance is forthcoming, or false certificates that performance has happened. A party in breach might maintain funds to pay a judgment, or she might manipulate her assets to make herself judgment proof. And a breaching party can often choose between settlement and litigating a meritorious claim against her.

In prior work I have called behavior that increases nonbreaching party's costs of obtaining compensation "obstruction of recovery," as distinguished from "cooperation in recovery." efficiency of the expectation measure in two ways. First, it adds transaction costs. Obstructive behavior increases the nonbreaching party's costs of securing the recovery to which she is entitled and can itself be costly to undertake. Because the efficient breach theory relies on a story about relative transaction costs, it should not tolerate obstruction of recovery. Second, a self-interested rational breaching party will choose obstruction only when she expects it to reduce the chances that she will have to pay for her breach. Obstruction therefore also threatens the efficiency of the incentives that the expectation measure is supposed to provide. Obstruction not only makes efficient breaches costly. It also makes it less likely that a breach is efficient.

The efficient way to breach a contract is to inform the other side that one will not be performing and volunteer to pay expectation damages. The inefficient way to breach a contract is to hide the fact of breach, to refuse a request for damages, to drag out litigation, or to otherwise obstruct recovery. On the theory, efficient breaches of the first type should be celebrated; efficient breaches of the second type condemned.

46. Klass, supra note 44. 


\section{Further Parallels}

Just as La Règle $d u$ Jeu depicts a society in which there is a right way and a wrong way to engage in infidelity, a fully articulated theory of efficient breach distinguishes between good and bad efficient breaches. The rules that govern tolerable transgressions in the two stories are not the same. The rules of infidelity, as depicted in the film, require discretion and detachment. The rules of efficient beach require transparency and taking responsibility. That said, the similarities between the two stories are more than structural.

First, the fact that both stories identify correct and incorrect transgressions makes room for an ethics, and even a morality, of nominally transgressive behavior. Two examples from La Règle du Jeu illustrate. In their first extended scene together, Octave is furious at André for having wronged Christine by announcing his love for her on the radio.

Octave: And you, instead of playing out your role of national hero, calmly and modestly, start to shoot off for your listeners ... well, instead of that, you start telling them about Christine... whom they've never heard of ... about Christine, in public ... just like that. And after that, you're surprised that she shuts her door in your face.

André: But if I made this flight, if I crossed the Atlantic ... it was because of her ... only because of her, you understand.... It was she who encouraged me. So when I saw that she wasn't even there when I landed . . .

Octave: You forget that she is a woman of the world ... and that particular world, it has its rules-very stiff ones. ${ }^{47}$

André does not wrong Christine by pursuing her despite her marriage to Robert, but by violating the rule of discretion. Later in the film it is Octave who almost violates the rules by planning to run away with Christine despite the fact that he is unable to financially support her. Now it is Lisette who plays the moralist.

Lisette: You're wrong, Monsieur Octave!

Octave: (surprised) Why wrong?

Lisette: Because when it's a question of having fun, just that, it's not important at all. But living together, the two of you ... I think one should leave the young with the young and the old with the old! ${ }^{48}$

Octave-himself something of a moralizer-realizes that his passion for Christine is about to lead him to harm her, and so sends André to her in his stead. Although the world depicted in La Règle du Jeu is not one of conventional morality, it is neither immoral nor amoral. It is not immoral

47. SCREENPLAY, supra note 10 , at 42 .

48. SCREENPLAY, supra note 10 , at 161 . 
so long as everyone understands the nature of the game they are playing. It is not amoral because within that game it remains possible to distinguish behavior that is morally right from behavior that is morally wrong.

Along the same lines, the distinction between permissible and impermissible efficient breaches allows Markovits and Schwartz to claim that their theory describes a "commercial morality of the exchange transaction." ${ }^{.49}$ As noted above, Markovits and Schwartz are of the view that contractual commitments between sophisticated parties are commitments not to perform, but to perform or pay damages. They denominate the failure to either perform or pay a "true breach." A true breach is the functional equivalent of what $I$ have called obstruction of recovery. Because true breach is never efficient, the theory of efficient breach treats it as wrongful.

[W] hereas [first-generation economic] approaches assimilate 'efficient breach' to the absence of an obligation, we assimilate 'efficient breach' to an obligation's performance; and whereas traditional economic theories of efficient breach understand the expectation remedy as a mechanism for identifying cases in which promisors are not obligated at all, we understand the expectation remedy as a direct enforcement of promisor's contracts. ${ }^{50}$

A party's failure to perform when performance is inefficient does not wrong the other side. But her subsequent failure to pay damages, and even more her actions calculated to avoid paying them, do. Because efficiency and party choice identify correct and an incorrect ways to efficiently breach a contract, the theory of efficient breach can also be a moral theory.

The second substantive similarity between the moral universes of $L a$ Règle $d u$ Jeu and the theory of efficient breach concerns the response to such wrongs. In both stories, "true breaches" should not be priced, but punished. The punishment in La Règle du Jeu is banishment from the society of La Colinière. ${ }^{51}$ After the chase through the house, Robert dismisses both Schumacher and Marceau. Schumacher's unwillingness to tolerate his wife's affair with Marceau means that he cannot function within that society. Marceau has not violated those rules. He is something of an innocent victim in the whole affair. But as Robert apologetically and with some irony explains, "It is difficult for me to throw Schumacher out and to leave you here with his wife. I'm sure you understand that would be immoral." 52 André, who has allowed himself to fall in love with Christine, is shot and killed in a case of mistaken identity. He too, in the end, leaves the society of La Colinière. ${ }^{53}$ Finally, in the penultimate scene Octave sets

49. Markovits \& Schwartz, supra note 27 at 1943.

50. Id. at 1986.

51. See SESONSKE, supra note 11, at 410 (noting at the end of the film three interlopers are expelled: Octave, André and Marceau).

52. SCREENPLAY, supra note 10 , at 147.

53. Sesonki makes a similar point about the meaning of André's death: 
off on foot to the train station, telling Marceau from now on he must "try to manage on my own" in Paris. ${ }^{54}$ In the end, all the men who have been involved in serious violations are forced to leave La Colinière. The social world depicted in the film can tolerate the transgression of infidelity. But it cannot tolerate those who violate the rules that govern infidelity.

In a fully articulated theory of efficient breach, the same holds true for obstruction of recovery. Because obstruction, or "true breach" in Markovits and Schwartz's idiom, is never efficient, ${ }^{55}$ the theory recommends penalizing it, deterring it tout court, rather than pricing it. Thus in Markovits and Schartz's account, the nonperforming party is not given the option of true breach. "[T]he expectation remedy is specific performance of the promise to transfer." ${ }^{56}$ I have argued that on the model specific performance of the payment term might be too weak a sanction.

Injunctive relief ... does not penalize the initial nonconsensual taking. Instead, an injunction clarifies what the entitlement is and establishes that any future nonconsensual taking of it will be penalized by civil or criminal contempt. Why should contract law give the promisor who has refused to act or transfer a do-over? The theory supports awarding punitive damages to the promisee who has been forced to go to court to vindicate her entitlement to performance of the disjunctive obligation. ${ }^{57}$

The efficient breach theory supports supercompensatory remedies such as punitive damages or disgorgement-certainly for actively obstructing the recovery of damages, and perhaps also for passively declining to pay them. Markovits and Schwartz agree in principle, but argue that specific performance is preferable in light of "pragmatic difficulties that are internal to the effective articulation and administration of a punitive regime. ${ }^{" 58}$ Whether these pragmatic difficulties are insurmountable is an empirical question. The important point is that according to the efficient breach theory, failures to abide by the rules of efficient breach should be met with penalties rather than prices.

If we have attended to the rules of the killing game, it may appear that the death of Andre Jurieu occurs quite in accord with the etiquette of la chasse. As a utilitarian act, clearing the master's domain of one more invading rabbit, it falls quite properly to a servant, and quite precisely to Schumacher. But if, as Renoir says, it is also a sacrifice on the alter of God so that the bourgeois life may continue for a while, then Robert, the master, must authenticate the rite-as he does by proclaiming the death an accident. Hence, perhaps, the propriety, in this bourgeois world, of the general's final verdict on the deed: "No, no, no, no, no. This La Chesnaye does not lack class."

SESONSKE, supra note 11 , at 400.

54. SCREENPLAY, supra note 10 , at 166.

55. Klass, supra note 44 at 56 ("Obstructive breach is rarely efficient."); Markovits \& Schwartz, supra note 27, at 1949 ("no true breach is efficient").

56. Markovits \& Schwartz, supra note 27, at 1987.

57. Klass, supra note 28 , at 149; see also Klass, supra note 44 , at 54-60 (arguing that punitive damages are often the appropriate response to obstruction).

58. Markovits \& Schwartz, supra note 27, at 1990. 
Efficient breach theorists rarely emphasize this result. But it should not surprise. In the language of Calabresi and Malamed, the efficient breach story characterizes the entitlement to contract performance as protected by a liability rule. ${ }^{59}$ Expectation damages give parties the option to perform or pay. But a legal system cannot operate with liability rules all the way down. ${ }^{60}$ The entitlement holder's right to payment for the taking must eventually be protected by a property rule. Jules Coleman and Jody Kraus make a similar point with respect to liability rules in tort law.

Despite having a system of injunctions and tort-like remedies to enforce certain claims, an enjoined party liable in torts might refuse to pay damages. A criminal law might then be necessary to enforce compliance. In this sense the criminal law is always in the background of the transaction structure, supporting the whole. The criminal law, or some institutional arrangement very much like it, is therefore necessary to enforce the primary means of institutional relief. $^{61}$

No matter how permissive a social norm is, if there is a norm-if there remain rules to the game - it must be possible to identify interpersonal assessments of when the norm is violated and the application of some negative sanction for such violations. ${ }^{62}$ In La Règle du Jeu, failures to adhere to the rules of infidelity result in expulsion from the society in which the game is played. On the theory of efficient breach, the nonbreaching party's entitlement to damages should be protected by a property rule, which is to say that obstructive behavior should not be priced but punished.

Although a fully elaborated theory of efficient breach supports penalizing both opportunistic breaches and obstruction of recovery, the stories that efficient breach theorists tell typically involve neither. Efficient breach theorists tell stories about efficient breaches. That choice is understandable. On the theory, efficient breaches both explain the law's attachment to the expectation measure and generate the surprise ending that makes the theory interesting: the law is structured to sometimes encourage breach. But that focus has also contributed to popular confusion

59. Guido Calabresi \& A. Douglas Melamed, Property Rules, Liability Rules, and Inalienability: One View of the Cathedral, 85 HARV. L. REV. 1089 (1972).

60. For some attempts to go as far as possible with multiple layers of liability rules, see IAN AYRES, OPTIONAL LAW: THE STRUCTURE Of LeGAL ENTITLEMENTS (2005); and Ian Ayres \& Jack M. Balkin, Legal Entitlements as Auctions: Property Rules, Liability Rules, and Beyond, 106 YALE L.J. 703 (1996)

61. Jules L. Coleman \& Jody Kraus, Rethinking the Theory of Legal Rights, 95 YALE L.J. 1335, 1336 (1986); see also Alan K. Klevorick, On the Economic Theory of Crime, 27 NOMOS: CRIMINAL JUSTICE 289 (J. Pennock \& J. Chapman eds., 1985) (arguing that liability rules establish transactions structures that are enforced by the criminal law).

62. For the same point at a much higher level of abstraction, see ROBERT B. BRANDOM, MAKING IT EXPLICIT: REASONING, REPRESENTING AND DisCURSIVE COMMITMENT 32-36, 42-46 (1998) (describing the conditions of normativity as including the practical normative attitude of assessment and the ability to identify sanctions for violations). 
about just what the theory does and does not say. I know of no systematic study of judicial application of the theory of efficient breach. But two examples suggest that courts do not always appreciate its nuances.

US ex rel. O'Donnell v. Countrywide Home Loans concerned Countrywide Home Loan's knowing and undisclosed delivery to Fannie Mae and Freddie Mac of billions of dollars in bundled nonverified subprime loans, despite the company's promise to provide only "investment quality mortgages." 63 On appeal, the Second Circuit overturned a jury finding of fraud. The court's reasoning as a whole did not rely on the theory of efficient breach. Yet in explaining why the $\$ 1.27$ billion penalty was inappropriate, the Second Circuit appealed to "the common law's tolerance for, even encouragement of, so-called 'efficient breaches' that increase overall wealth." ${ }^{64}$ This is extremely odd. Countrywide's breach was anything but efficient. The practice of granting sub-prime mortgages to unqualified borrowers, then bundling and selling them off to unsuspecting investors did not create new value. In fact, the widespread practice almost triggered a collapse of the national economy. Given the opportunistic nature of Countrywide's breach and its massive negative externalities, the mere mention of the theory suggests a basic confusion about what behavior the theory tolerates and what behavior it would punish.

Even more problematic is the Eleventh Circuit's reasoning in United States $v$. Blankenship, an appeal from a criminal fraud conviction stemming from a government contract with a minority-owned business. ${ }^{65}$ The court explained as follows why the business owner's contractual promises to do work that he intended to give to someone else could not possibly be false:

A contract is a document that serves only to establish a legal relationship between two parties; it gives each party nothing more than a legal expectancy in having the other party either perform or (generally) respond in damages. It is not illegal for a party to breach a contract; a contract gives a party two equally viable options (perform or pay compensation), between which it is generally at liberty to choose. A "promise" contained in a contract is not a certification that the promisor will actually perform the specified acts, or presently intends to perform those acts, but is instead a grant of a legal right to the other party to either enjoy performance or receive damages. Indeed, the whole notion of

63. US ex rel. O'Donnell v. Countrywide Home Loans, Inc. 2016 WL 2956743, Nos. 15-496, $15-$ 499 (2d Cir., May 23, 2016).

64. Id., slip op. at 20 (citing Thyssen, Inc. v. S.S. Fortune Star, 777 F.2d 57, 63 (2d Cir. 1985)

(Friendly, J.).

65. United States v. Blankenship, 382 F.3d 1110 (11th Cir. 2004). 
"efficient breach" is that a party should abrogate its contractual responsibilities if a more profitable opportunity comes along. ${ }^{66}$

This reasoning is deeply confused. The theory of efficient breach in no way recommends doing away with the doctrine of promissory fraud ("a certification ... that the promisor ... presently intends to perform"). ${ }^{67} \mathrm{~A}$ promise that the promisor intends to breach from the outset does not create social value, but merely results in a damage payment from one side to the other. Neither efficiency nor morality supports tolerating such bad behavior.

Two judicial opinions do not demonstrate pervasive confusion about the theory of efficient breach. And some judges get the theory right. ${ }^{68}$ But the examples, both from US Courts of Appeals, illustrate the worry. Some wrongs between even sophisticated contracting parties can be punished without sacrificing either efficiency or morality. And the thinking in these cases is consistent with more general features of our law of contracts. Although courts have dabbled with punitive damages for post-breach obstruction, most famously in Seaman's Direct Buying Service v. Standard Oil Co. ${ }^{69}$ those experiments have been largely abandoned.$^{70}$ And though some forms of obstruction satisfy the elements of the tort of deceit, many courts apply the economic loss rule to bar such claims between contracting parties. ${ }^{71}$ Other than generic rules against obstructive behavior during litigation, such as Rule 37's provision of sanctions for the failure to cooperate in discovery, ${ }^{72}$ perhaps the only clear example in US law of a punitive response to obstructive breach is the False Claims Act, which imposes treble damages and per-claim fines on government contractors who submit false invoices. ${ }^{73}$ That rule, however, applies only to government contracts.

In short, the story of efficient breach that gets told and retold in popular legal culture simplifies too much. Just as infidelity in La Règle du Jeu remains highly regulated, so too a commitment to efficiency should distinguish between good and bad breaches. A more complete theory of efficient breach includes stories about opportunistic breaches and obstruction of recovery. Thinking about the correct legal response to breaches of these types reveals a degree of correspondence between efficiency and morality, just as the film depicts an internal morality of

66. Blankenship, 382 F.3d at 1133-34 (internal citations omitted).

67. For more on this topic, see IAN AYres \& GREGORY KLASS, INSINCERE Promises: THE LAW OF MISREPRESENTED INTENT 59-82, 90-99 (2005).

68. See, e.g., Patton v. Mid-Continent Sys., Inc., 841 F. 2d 742, 751-52 (7th Cir. 1988) (Posner,

J.); Freeman \& Mills, Inc. v. Belcher Oil Co., 900 P.2d 669, 683-84 (Cal. 1995) (Mosk, J., dissenting).

69. 686 P.2d 1158 (Cal. 1984).

70. See id. (overruling Seaman's).

71. See Klass, supra note 44 , at 41-49.

72. FED. R. CIV. P. 37.

73. I explore the workings of the False Claims Act in Michael Holt \& Gregory Klass, Implied Certification under the False Claims Act, 41 PUB. CONT. L.J. 1 (2011). 
infidelity. As it is, common misunderstandings about the efficient breach theory's scope can, even in cases involving sophisticated parties, lead to outcomes that are both inefficient and morally unsatisfying.

\section{THE MORAL VALUE OF THE GAME}

Up to this point, I have described the plot and structure of La Règle $d u$ $\mathrm{Jeu}$ largely from the perspective of members of the society the film depicts - from the internal point of view of a competent player of the game of infidelity. From that perspective, behavior that conventional morality marks as a wrong is in fact permissible, but only when done in the right way. This is the internal morality of infidelity in the film, or the rules of that game.

La Règle du Jeu is not, however, a morality play about the right and wrong ways to commit adultery. Renoir does not adopt the perspective of his characters or the society they inhabit. He is a social critic, and the film suggests that the social world it depicts is not a healthy one. The diseases are manifold. Here I focus on two. Each points the way toward a more sophisticated moral criticism of the theory of efficient breach.

\section{A. The Value of the Practice}

The first moral criticism concerns the conditions for human flourishing and is illustrated by the character of Robert de la Chesnaye. Robert has completely internalized the rules of his social station. As the cook marvels, he is the sort of gentleman who can tell right away when the potatoes in the salad were not properly doused with white wine after boiling. Robert is the consummate host, who after an evening of chaos and gunshots puts his guests at ease on their way to bed with a few fabrications and gentle reassurances. And he understands the rules and plays the game of infidelity better than anyone. He is both an attentive husband to Christine and, when the film begins, a reliable inamorato to Geneviève. And he remains a generous and gregarious friend to André, despite André's public affair with Robert's wife. As the General puts it in the film's last line, "La Chesnaye does not lack class." "74

But Robert is also a pitiable figure. In his first scene, he demonstrates to Christine his newly acquired "little romantic Negress"-a music box with a mechanical depiction of a black woman. Robert is a collector of mechanical musical figures, which are the object of his devotion. At La Colinière, he shows off to his guests his greatest acquisition, a large calliope, "the culmination of my career as a collector of musical and mechanical instruments." " In what Renoir described as "the best shot I've

74. SCREENPLAY, supra note 10 , at 168.

75. Id. at 133. Reinoir later said that this scene "provides the clearest explanation of the character of La Chesnaye." Interview in Sologne (with Office de radiodiffusion-télévision française), reprinted in SCREENPLAY, supra note 10, at 9, 12. 
done in my life," the camera pans across three mechanical men and then onto Robert's face, which expresses a "mixture of humility and pride, of success and doubt."76 Robert prefers the simulacrum of life to the real thing and is as hollow as the mechanical toys he cares so much for. He does not live an authentic life, but plays at life according to the rules of the society he occupies.

The depiction of Robert is but one charge in the film's general indictment of the social order he epitomizes. I am not the first to note Renoir's critical attitude. Leo Braudy writes: "La Règle $d u$ Jeu embodies a social world in which there are rules but no values. If you don't know the rules, you are crushed; but if you do know the rules, you are cut off from your own nature." 77 So too Alexander Sesonske, who describes SaintAubin and La Bruyere's petty arguments about the rules of the hunt as follows:

In a field strewn with slaughtered game, they heatedly dispute the etiquette of the hunt-the living game means nothing if the rules of the game are breached. These exchanges show perhaps how thin the veneer of civility is; within the double brackets Renoir displays the savagery that smolders underneath. ${ }^{78}$

The guests at La Colinière are in turn clueless, hapless, petty, cruel, foppish, childish, needy, and absurd-epitomized by Madame La Bruyere, who explains to a servant that she takes salt in her food, "but only sea salt, and added only after cooking." ${ }^{.79}$ It is a decadent society. At the beginning of the film, Christine exclaims, "Oh well, what is natural nowadays." 80 Renoir's message is that nothing in the society he depicts is the least bit natural or healthy.

The general indictment applies also to the game of infidelity. The game is unnatural. Its rules of detachment and discretion do not allow for genuine human relationships. This is demonstrated inter alia by Christine's impact on the men around her. An Austrian, Christine does not belong to Parisian high society. ${ }^{81}$ Her presence is disruptive because, in distinction to those around her, she seeks authentic relationships. She shows André, Robert and Octave an alternative, more natural, and more attractive form of romantic love than their society offers, causing each to act in ways that upsets the equilibrium that the rules of infidelity otherwise maintain. André falls too deeply in love; Robert attempts to break off his affair with Geneviève; Octavio nearly betrays his friendships with both

76. Interview, supra note 75 , at 12 .

77. LEO BRAUDY, JEAN RENOIR: THE WORLD OF HIS FILMS 132 (1972).

78. SESONSKE, supra note 11 , at 398.

79. SCREENPLAY, supra note 10 , at 66 .

80. Id. at 31 .

81. Saint-Aubin: "Poor Christine, I feel sorry for her, because she is a foreigner." Id. at 37 Octave: "after all, the girl's not at home, she's in a foreign country; the people around her don't speak her language." Id. at 41 . Christine's father was a great Viennese conductor, whereas her husband collects mechanized musical instruments. 
André and Robert. All are moved by the possibility of a love that is more human than "an exchange of whims and the contact of skins," all the game of infidelity can provide.

One can imagine a similar charge against the theory of efficient breach. The choice-based theory of efficient breach argues that naïve moral criticisms misunderstand the game sophisticated parties are playing. Sophisticated parties are contracting for efficient breaches. So long as damages are paid, an efficient breach is not a broken promise. It is not a "true breach." Faced with this response, the moral critic might ask instead about the relationships such promises underwrite. Do the attitudes, acts and commitments that the theory of efficient breach recommends compose an attractive picture of moral character and human relations? Like the game of infidelity in La Règle $\mathrm{du} \mathrm{Jeu}$, perhaps the game of efficient breach is itself morally problematic. Perhaps it envisions a form of interaction that does not allow for human flourishing. Perhaps those who take the theory of efficient breach to heart will find themselves treating others as means rather than ends and in a way that undermines the development of more authentic or valuable forms of sociability. ${ }^{83}$

Joseph Raz has suggested that if we want to understand the moral obligation to keep a promise we should begin with an account of why the abilities to make and to accept promises are morally valuable. ${ }^{84}$ Along these lines, Seana Shiffrin has argued that promises are necessary for maintaining the intimate relationships essential to a full moral life. ${ }^{85}$ When two friends attach different values to some shared project, the one who cares more can be left vulnerable. The other side's promise to participate addresses that vulnerability by giving the insecure party the power to demand performance and affirming the value of her preferences and judgments. ${ }^{86}$ David Owens has identified a somewhat different moral

82. Id. at 37-38. See supra note 12 .

83. For additional thinking along these lines, see Avery Katz, Virtue Ethics and Efficient Breach, 45 SUFFolK U. L. REV. 777, 791-97 (2012); and Shiffrin, Divergence, supra note 29, at 740-49.

84. See Joseph Raz, Promises and Obligations, in LAW, MORALITY AND SOCIETY: ESSAYS IN HonOuR OF H.L.A. HART 210, 228 (P.M.S. Hacker and Joseph Raz eds., 1977) ("[Promise] principles can only be justified if the creation of such special relationships between people is held to be valuable.").

85. Seana Valentine Shiffrin, Promising, Intimate Relationships, and Conventionalism, 117 PHIL. REV. 481 (2008).

86. Shiffrin illustrates with the following example: Suppose, A and B are together engaging in some project, such as moving to a new city, and that $A$ has a greater interest in its success than does B. This difference can cause $A$ to be vulnerable to $B$, and that vulnerability can degrade their relationship. $B$ 's ability to commit to the project with a promise prevents such degradation.

Promising to $\varphi$ conveys B's willingness to forswear the moral right to alter course. B's participation is no longer dependent on how $B$ perceives the merits of the activity at the time of action. The promise acknowledges A's investment in the situation in a way that includes $A$ rather than making $A$ a bystander to what unfolds. . The promise to $A$ does not just increase the likelihood of B's performance (if it does so at all) but actively affirms A's status as a free person, capable and worthy of exercising sound judgment about what is to be done. B's relinquishment and transfer of that power to A works to neutralize aspects of the situation's hazards and to restore an equal standing between $\mathrm{A}$ and $\mathrm{B}$ in this local domain. 
interest promising serves, which he calls the "authority interest." ${ }^{187}$ Owens argues that humans have an interest in being able to control the "normative landscape"-in being able to shape their own rights and obligations and those of people around them. ${ }^{88}$ Like Shiffrin, Owens explains the value of promises by looking to the challenges of acting together. But whereas Shiffrin emphasizes the quality of the relationship, Owens focuses on the promisee's interest in being able to decide whether performance is required ${ }^{89}$ A promise, as Owens emphasizes, gives the promisee a new normative power: to determine whether or not the promisor has a moral duty to perform. In doing so, it expands the promisee's autonomy and serves her moral interests.

These are only two possible accounts of the value of being able to make morally binding promises. But either could be used to make a case for the moral deficits of the obligations that the choice-based efficient breach theory imagines. A promisor who undertakes a duty only to perform or pay damages retains a degree of discretion that leaves the promisee vulnerable. The promisee can no longer count on performance, and therefore remains at the promisor's mercy. As Shiffrin writes, such a promisor "has usurped [the promisee's] ability to make independent, voluntary decisions about the use and form of [the promisee's] time, attention and labor." ${ }^{90}$ Nor does an efficient breach promisor grant the promisee the degree of authority over her that Owens finds valuable. The recipient of an efficient-breach promise cannot determine whether the promisor is obligated to perform, but can absolve her only from the obligation to pay damages. Even if a promise to perform or pay is still a promise, the content of that promise tends to undermine, rather than foster, the values promising serves.

Shiffrin's and Owens's accounts of the moral value of the practice of promising suggest why one might find the content of efficient breach promises morally problematic. If such commitments erode rather than support the special relationships and autonomy interests that the practice of promising underwrites, perhaps we should worry about the moral culture they create. A promise to perform or pay damages, no matter what

\footnotetext{
Id. at 507-08.

87. David Owens, A Simple Theory of Promising, 115 PHIL. REV. 59 (2006).

88. Owens further develops these ideas in DAVID OWENS, SHAPING THE NORMATIVE LANDSCAPE 143-53 (2012).

89. Or as Owens writes:
}

[S]omeone motivated to insist on the right to decide for themselves what they are going to do will also be motivated to seek the right to require another to behave in a certain way, where their own decisions depend on the actions of that other person. And, in return for receiving this right, they may be willing to sacrifice their own freedom of action in some matter of less importance to themselves. A promise effects such grants of authority.

Owens, supra note 87 , at 70 .

90. Seana Valentine Shiffrin, Could Breach of Contract Be Immoral, 107 MICH. L. REV. 1551, 1564 (2008). 
its price effect and no matter what the promisee's preferences, expresses an attitude towards the promisee at odds with a healthy moral relationship.

Although I believe such practice-based moral criticisms avoid the pitfalls of the naïve moral objection to efficient breach, I do not think they are decisive. The above arguments, or something like them, might show that a promise to perform or pay would be inappropriate, and even harmful, among friends or other intimates. But not everyone is, or should be, my friend. Human sociability is multilayered, and valuable relationships take many forms.

Daniel Markovits, for example, has argued that contractual commitments underwrite a distinctive form of sociability, one that "replaces a concern for other persons' interests - the concern that underwrites the sharing of ends involved in typical personal promiseswith a concern for other persons' intentions and, ultimately, for their points of view." ${ }^{.91}$ Parties to a contract do not bind themselves to one another, but to the project to which they have agreed. They undertake to collaborate on that project, but not necessarily to cooperate with one another in it, where "cooperation" is understood to involve commitment to broader shared purposes or reciprocal care. A promise to perform or pay damages does not undermine this relatively thin form of sociability. Although the efficient breach promisor does not grant the promisee the type of authority that Shiffrin or Owens describes, she does commit herself to the project that the parties have together chosen. And though this might mean that the parties are not interacting as friends or intimates, it does not follow that their relationship has no value. On the contrary, the joint commitment to the project involves its own form of mutual respect and even solidarity. It is not friendship, but a form of sociability that has a value of its own.

It would be odd to claim that La Règle du Jeu perfectly captures everything one might say about the theory of efficient breach. But Renoir's story is rich enough that one can find in it an analog to the above defense of efficient breach promises. After Christine runs off with SaintAubin, Robert and André engage in a fistfight over her. When the fight is interrupted by a gunshot from Schumacher, the two immediately begin working together, initially to control the drunkenly manic Geneviève and then to hide the debacle from the other guests. Soon they are acting like friends, each complimenting the other on his fighting abilities and then discussing the practical details of André's departure with Christine because, as Robert explains, "I love her so much ... that I want her to leave with you. ${ }^{92}$ Robert and André are of the same social set--Robert is pleased that Christine "has picked someone from our milieu." 93 Perhaps

91. Daniel Markovits, Contract and Collaboration, 113 YALE L.J. 1417, 1451 (2004).

92. SCREENPLAY, supra note 10 , at 148 .

93. Id. 
the rules of infidelity will prevent either from ever having a genuine loving relationship with Christine. But their mutual understanding of the rules of their social class, including the need for emotional distance and dissimulation, forms the basis of a mutual respect and a type of friendship between them. Although Robert believes he has lost his wife to André, he apparently does not believe that André has wronged him. If in the social world of La Colinière authentic love is undermined by a practice of infidelity, other forms of sociability remain possible. Those other forms might even be enabled by the rules that thwart romantic love.

Is the friendship between Robert and André one we should value? Should we value the uncaring but respectful collaborative relationships that correspond to a promise to perform or pay damages? Such questions cannot be answered in the abstract. More convincing than any argument from first principles will be stories about the sort of sociability at issue. Patricia Williams has powerfully described the value that, as a black woman, she finds in legally structured relationships. She explains her preference for a formal legal relationship with her landlord as follows:

I ... was raised to be acutely conscious of the likelihood that, no matter what degree of professional or professor I became, people would greet and dismiss my black femaleness as unreliable, untrustworthy, hostile, angry, powerless, irrational, and probably destitute. Futility and despair are very real parts of my response. Therefore it is helpful for me, even essential for me, to clarify boundary; to show that I can speak the language of lease is my way of enhancing trust in me and my business affairs. ${ }^{94}$

Williams's scholarship illustrates the power of such stories to reshape how some might think about the meaning of one or another type of social relationship. Whereas the friendship between Robert and André relies on their shared membership in the upper class, contractual relationships reflect the formal equality of the market. Williams suggests that the distant but respectful relationships of formal contracting, in which one relies not on the other party's character but on the content of her obligations, can be empowering, as it presupposes each party's independence and selfsufficiency. If the theory of efficient breach does not demand the sort of commitment that underwrites intimate relationships, its emphasis on autonomy and self-sufficiency also signals a type of respect. That respect is valuable in general and sometimes especially to members of otherwise disadvantaged or marginalized groups.

The meaning and moral worth of any social practice depends on the social context in which it occurs. One final example, which brings us back to Renoir, can be found in Praveen Krishna's helpfully titled short story,

94. Patricia J. Williams, Alchemical Notes: Reconstructing Ideals from Deconstructed Rights, 22 HARV. C.R.-C.L. L. REV. 401 (1987). 
Efficient Breaches: A Romance. ${ }^{95}$ Krishna tells of a couple in an arranged marriage who, through extramarital affairs, discover otherwise impossible forms of shared intimacy with one another. Whereas the game of infidelity in La Règle du Jeu alienates the characters from their natural selves, discrete and detached adultery plays a positive role in Krisha's story. It ends as follows:

As Sunita recounted this anecdote, recounted to her by a man who was recounting it to himself, Narayan suddenly understood that what he was hearing was not simply an anecdote, but a confession. Or a boast. The lightness in her voice, the enthusiasm, the nerves - whoever had told her this story was someone she was sleeping with.

He would have never expected it of her. He was proud of his wife. He hoped she did not feel guilty; he would have never wanted that for her. He wanted to talk about it with her, to give her advice, but she wouldn't have liked that. He had to be quiet for her just as, after dinner, in bed, when Sunita whispered to him new things to try, Narayan pretended to be ignorant. ${ }^{96}$

Both the value and the effects of a social practice commonly depend on the broader social context in which it occurs. This holds equally for the attitudes fostered by a promise to perform or pay damages.

The above observations are not a complete defense of the theory of efficient breach from the practice-based moral criticism. But I think they are enough to show that the criticism must do more than appeal to a general theory of promising. Another way of putting the point is that it is wrong to conflate contractual commitments with other sorts of agreementbased or promissory obligations, or to assume that they serve the same values. ${ }^{97}$ A practice-based moral criticism of the theory of efficient breach requires an account of why the attitudes and relationships that the theory depicts are, in the contexts in which they occur, themselves morally problematic. It is not enough to demonstrate that they do not correspond to other morally valuable attitudes and relationships.

\section{B. Effects on Nonplayers}

There is, however, a second possible moral criticism of the choice-based theory of efficient breach. This one emphasizes the theory's narrative power and its potential effects on transactions that do not fit its model, and especially on parties who do not conform to its expectations. This worry too has its counterpart in La Règle du Jeu: the practice of infidelity's

95. 91(4) VA. Q. REV. 126 (2015)

96. Id. at 135 .

97. See Gregory Klass, Promise Etc., 45 SuffolK U. L. REV. 695 (2012). 
effect on those who do not participate in it, whether because they do not understand its rules or because they seek a different form of relationship.

Consider Schumacher, the Austrian gamekeeper. In most of the film, Schumacher's rigid conventionalism and Teutonic rule worship serve as comic fodder. But the last fifteen minutes show another side of his character. After Marceau is ejected from the house, he happens upon Schumacher standing alone by a stream. The poacher begins to sneak by, but sees that Schumacher is quietly crying to himself. In a close-up, the audience sees the tears streaming down Schumacher's face and Marceau's sudden sympathy. The two sit together and discuss what each will do next. Schumacher will stay in the area, near his wife whom he still loves. Lisette, who plays the game of infidelity with gusto, has treated Schumacher with nothing but contempt. Early in the film, the audience is invited to share in that attitude. Now Schumacher's grief and resolve cast Lisette's disregard in a new light. Her lighthearted, flirtatious fun and attachment to Paris and to her employer's values have led Lissette to mistreat Schumacher, who nonetheless remains deeply in love with her. Schumacher now appears a noble character, whom Lisette has wronged.

The moral defect here is not so much the game itself, as the fact that it being played with a person who does not understand its rules or wish to play it. Sesonske, emphasizing Gaston Modot's performance as Schumacher, suggests a similar reading:

As Schumacher he is flawless, an upright servant with pride in his profession, a man of principle, baffled and outraged by a world from which principles have disappeared-comic, tragic, ludicrous, pitiful - the major symbol in La Règle du Jeu of the impact of the haut bourgeois style on traditional mores. ${ }^{98}$

Schumacher, in the end, is a tragic figure. The fault lies neither in his stars nor in himself, but in his dislocation to a society where he does not belong.

The tragedy of Schumacher reflects the tragedy of Christine. After she spies Robert kissing Geneviève, Christine realizes that "[f]or three years my life has been based on a lie." 99 She decides to give up on authentic friendship or love, and inexpertly throws herself into game of infidelity. That evening she woos Saint-Aubin-a cynic, an ass, and a character Christine could never love. Her pursuit of Saint-Aubin, together with Schumacher's discovery of Marceau and Lisette, set into motion the evening of mayhem that ends with Andre's death, for which Christine must hold herself responsible. In short, no matter what the inherent morality or immorality of the game of infidelity, it presupposes that everyone involved plays by its rules. When nonplayers are caught up in it, they are likely to be harmed and to cause harm.

98. SESONSKE, supra note 11 , at 426.

99. SCREENPLAY, supra note 10 , at 155 . 
One might similarly worry about the tendency of the theory of efficient breach to escape its proper bounds. Early versions of the theory aimed to explain contract law's generic preference for the expectation remedy. They were theories of contract law as a whole. Later iterations acknowledge the theory's assumptions, which include sophisticated parties, competitive markets, cheap adjudication and high costs of negotiating a release. But when a theory tells a simple, compelling story it is easy to forget its premises. There is a long tradition in Anglo-American contract law of idealizing agreement and ignoring the conditions in which agreement occurs. The efficient breach story employs familiar characters: independent and autonomous parties who are self-reliant, competent, knowledgeable and rational. Because the theory fits so easily into broader narrative about contract law, its rhetorical power and practical influence can extend beyond the reach of its assumptions.

I have already discussed one way simple stories of efficient breach can mislead. When courts appeal to the theory, they often ignore both the difference between efficient breach and opportunistic breaches, and the fact that it is not efficient to obstruct recovery. Even more troubling is the extension of theory to contracts involving parties who might not understand, appreciate or wish to be governed by its rules.

As choice-based efficient breach theories use the term, "sophisticated parties" refers to risk-neutral, fully informed, perfectly rational, selfinterested profit maximizers. If any legal personality approximates this description, it is perhaps the publicly traded corporation, in which ownership is divested from control, and control is given to a collection of highly trained managers who are tasked with one goal: maximizing shareholder profit. Many contracting parties are not sophisticated in this sense. When the efficient breach theory's recommended rules or attitudes are applied or adopted beyond the range of the theory's assumptions, it is much less likely to produce a morally adequate account of the transaction.

Although Peevyhouse v. Garland Coal \& Mining Company antedates the efficient breach theory by a decade, its familiar facts nicely illustrate the danger. ${ }^{100}$ In 1954, Willie and Lucille Peevyhouse leased their farm to Garland Coal \& Mining for strip mining. In addition to the payment of royalties, Garland Coal agreed that, at the end of the lease, it would repair the farm to "provide access to a small amount of land north of the pit, assure its future utility as pasture land, and enhance the safety of persons and livestock when near the pit." 101 Although not mentioned in the Oklahoma Supreme Court's opinion, the Peevyhouses waived a $\$ 3,000$ up-front cash payment in return for that promise to remediate. ${ }^{102}$ Garland

100. 382 P.2d 109 (Okla. 1962).

101. Judith L. Maute, Peevyhouse v. Garland Coal \& Mining Co. Revisited: The Ballad of Willie and Lucille, 89 Nw. U. L. REV. 1341, 1363 (1995).

102. Id. 
Coal extracted very little coal from the Peevyhouse farm, but diverted a creek onto it in order to mine elsewhere. At the end of its operations, Garland Coal failed to perform the promised remediation. The question before the court was the proper measure of damages where the evidence suggested that the cost to remediate the land would be $\$ 29,000$, and that remediation would add only $\$ 300$ to the farm's market value. The court held that because the promise to remediate was "incidental" to the lease and the market value of the work was grossly disproportionate to the cost of performing it, the Peevyhouses could recover only the $\$ 300$ diminution in value.

There are many things to criticize in the Peevyhouse decision, including, as the dissent pointed out, the majority's failure to recognize the importance of the remediation term, which the Peevyhouses had insisted on; Garland Coal's lack of excuse for its nonperformance, as it could have predicted the costs of remediation both at the time of contracting and when it decided to divert the creek; and the subjective value the Peevyhouses attached to their farm, which monetized must have been at least $\$ 3,000 .{ }^{103}$ Here I want to focus on something else: the possible gap between the Peevyhouses' and Garland Coal's attitudes toward contract performance.

We do not know, but it is easy to imagine that the Peevyhouses did not think they were granting Garland Coal an option to perform or pay damages - in any amount. Their benefit from the lease was contingent on the quantity of coal Garland took out of their land. What would remain at the end of the lease was their farm, which they would continue to occupy. In an interview years later, Willie Peevyhouse "explained his view that it was not right to take money for land and allow work to be done on it that would make the land worthless in the future." ${ }^{104}$ This is not to say that the Peevyhouses expected Garland Coal to treat them as friends. But it suggests that they believed they were receiving a commitment to perform, not to perform or pay damages.

We also do not know with certainty what Garland Coal's expectation or attitude was when it entered into the lease. But the company presumably knew the risk that it would be difficult to mine the coal on the land. And the record suggests that the only thing of substance that changed between Garland Coal's agreement to remediate and its choice to breach was the company's own decision to divert the creek onto the Peevyhouses' property. It is easy to imagine that Garland Coal believed that it was not committing to remediate, but only to remediate or pay damages.

Peevyhouse v. Garland Coal is a wonderful teaching case in part because it illustrates what can happen when parties have different understandings of the rules of the game. One might say that if the Peevyhouses had simply hired a lawyer, all this could have been avoided.

103. See 382 P.2d at 114-16 (Irwin, J., dissenting).

104. Maute, supra note 101 , at 1363. 
A good lawyer would have determined what her clients wanted from the transaction and sought to structure it accordingly. A lawyer might, for example, have suggested liquidating damages for breach of the duty to remediate, or the use of a performance bond. That answer, however, misses an equally important point. Parties contract for more than legal obligations. They enter exchanges with expectations about one another's attitudes towards performance. Those attitudes are material because they inform and influence each party's behavior under the contract. ${ }^{105}$ If the Peevyhouses believed that Garland Coal had an unconditional obligation to remediate, whereas Garland Coal viewed nonperformance as a permissible option, then something went wrong in their transaction. What was wrong, however, is not something that that the theory of efficient breach can comprehend. It lies outside of that theory's assumptions.

The above account of Peeveyhouse goes beyond what we know about the facts of the case. But one cannot understand the canonical contracts teaching cases without adopting hypotheses about what was really going on, both between the parties and on the bench. An appropriately critical understanding of the law requires thinking about both the stories that judicial opinions tell, and those they might choose not to tell. And as I have been at pains to emphasize, the theory of efficient breach also tells a story about who the parties are, what they want from their exchange transactions, and how the law figures into their attitudes and actions. The critical question about all such stories is whether they capture the salient facts. Peeveyhouse v. Garland Coal is a classic case because there's such a strong intuition that the majority missed something important in reaching its decision.

The issue is a general one. The law of contract applies to everything from an uncle's promise to give his nephew $\$ 5,000$ to refrain from drinking, smoking and gambling to a multi-million dollar long-term supply contract between two corporations. Theories of contract law, including theories that focus on contract remedies, tend to reach equally broadly. The danger in both law and theory is that the search for general rules or principles will cause us to neglect features of transactions that should figure into the legal outcome. The way for lawmakers to avoid that danger is to tailor rules based on who the parties are, on the relationship between them, and on the type of transaction they are entering into. This is why we have employment law, consumer law, a law for the sale of goods, securities law, a law of prenuptial agreements, and so forth. ${ }^{106}$ The way for theoreticians to avoid the danger of overgeneralization is to constantly

105. The common law tort of promissory fraud recognizes something like this point. See AYRES \& KLASS, supra note 67.

106. For a recent general defense of this approach, see HanOCH Dagan \& Michael Heller, THE CHOICE THEORY OF CONTRACTS (forthcoming 2017). 
keep the assumptions of the theory in mind, and to test them against the facts of the transactions that contract law governs.

Even sophisticated players might sometimes want more than a commitment to perform or pay. The Supreme Court's 2015 decision in Kansas v. Nebraska gets this right, though it comes out exactly the opposite way that the theory of efficient breach says it should. The case concerned a special master's award of disgorgement for breach of an interstate water compact. The disgorgement measure required Nebraska to pay not the value of Kansas's loss, but the profits Nebraska realized as a result of its breach. ${ }^{107}$ Justice Kagan's opinion all but says that Nebraska's breach was efficient. The special master had "concluded that an acre-foot of water is substantially more valuable on farmland in Nebraska than Kansas." 108 But rather than taking this fact as a reason to permit Nebraska to take and pay, Kagan treats the efficiency of the breach as a reason for additional deterrence.

Possessing the privilege of being upstream, Nebraska can (physically, though not legally) drain all the water it wants from the Republican River. And the higher value of water on Nebraska's farmland than on Kansas's means that Nebraska can take water that under the Compact should go to Kansas, pay Kansas actual damages, and still come out ahead. That is nearly a recipe for breach-for an upstream State to refuse to deliver to its downstream neighbor the water to which the latter is entitled.... In such circumstances, a disgorgement award appropriately reminds Nebraska of its legal obligations, deters future violations, and promotes the Compact's successful administration. ${ }^{109}$

In order to reach this conclusion, the Kagan relies in part on section 39 of the Third Restatement of Restitution and Unjust Enrichment. ${ }^{110}$ But that is a very thin reed. Section 39 lacks support in US case law and, as Justice Scalia observes, "should be given no weight whatever as to the current state of the law, and no more weight regarding what the law ought to be than the recommendations of any respected lawyer or scholar."111

If there is a good argument for the majority's decision, it is that Kansas and Nebraska were not playing the game of efficient breach. Kagan observes that interstate water compacts are created in the shadow of the

107. 125 S. Ct. 1042 (2015). For additional discussion of the case, see Caprice L. Roberts, Supreme Disgorgement 67 FLA. L. REV. (forthcoming 2016), available at: http://ssm.com/abstract $=2661109$.

108. Id. at 1056.

109. Id. at 1058 (internal quotation marks and citation omitted).

110. RESTATEMENT (THIRD) OF RESTITUTION AND UNJUST ENRICHMENT \& 39 (2010).

111. $125 \mathrm{~S}$. Ct. at 1064 (Scalia, J., dissenting); see also id. at 1068-69 (Thomas, J., dissenting) ("This Court, however, has never before relied on $\$ 39$ nor adopted its proposed theory of disgorgement. And for good reason: It lacks support in the law." (citing Caprice L. Roberts, Restitutionary Disgorgement for Opportunistic Breach of Contract and Mitigation of Damages, 42 LOYOLA L.A. L. REV. 131, 134 (2008))). 
Supreme Court's original jurisdiction to equitably apportion streams. Given that context, "it is difficult to conceive that a downstream State would trade away its right to our equitable apportionment if, under such an agreement, an upstream State could avoid its obligations or otherwise continue overreaching." 112 Going beyond the opinion, one might observe that interstate water compacts are not so much value-generating exchanges as attempts to agree upon a solution to a zero-sum division game. Given the circumstances in which the compacts occur, states are unlikely to have the preferences that the theory of efficient breach assigns to parties. From the perspective of the theory of efficient breach, Kansas v. Nebraska employs backwards logic and appears to come out exactly the wrong way. But there is a good argument that it gets the parties' ex ante preferences right.

Whether or not a practice of efficient beach is a morally satisfying one, the theory of efficient breach does not capture everything that is happening in all contractual transactions. More to the point, it does not capture everything that the law should take notice of. When only one party is playing the game of efficient beach, there is a risk that the party who believes she has contracted for performance will suffer unanticipated losses. When neither party is playing, courts should not apply its logic.

Whether one finds the practice of efficient breach morally sound or morally corrupt, one should keep the theory's assumptions and limits in view. Although the sophisticates in the society depicted in La Règle du Jeu might think that they are playing a game of mutual enjoyment in which no one is harmed, as the plot unfolds it becomes clear that they are operating on false premises. It turns out that their practice of infidelity harms participants by engendering attitudes that undermine more authentic relationships, and that it also harms those who do not understand or wish to participate in the practice by disappointing their expectations. When courts endorse the attitudes the efficient breach theory recommends in transactions that do not accord with the theory's assumptions, they are neither attuned to the moral situation nor likely to advance party welfare.

\section{CONCLUSION: STORYTELLING AND LEGAL CULTURE}

Sometimes a story becomes true through its telling. So too with legal theory. Legal theories do not stand outside of the social practices they describe. We teach them in law schools and they find their way into judicial opinions. The moral community a successful legal theory imagines can influence legal culture. This means that legal theories should

112. Id. at 1052 . 
be held accountable for, among other things, the moral value of the communities they depict and, in many cases, thereby affirm.

The theory of efficient breach is, among other things, a story many of us tell first-year law students. And it is well suited to the project of introducing students to the law. Contract law does not always track morality, and if a lawyer is to competently advise her client, she must know when they come apart. ${ }^{113}$ First-year law students must learn to sometimes put aside their intuitions about what morality requires so they can identify what the law demands. The theory of efficient breach is a good tool for teaching those skills. It disrupts untutored expectations about what the law requires of parties, about how we should choose legal rules, and about the sorts of obligations sophisticated parties themselves might want.

At the same time, one should pay attention to the lessons they, and we, draw from the theory. The theory of efficient breach is a just-so story about an important band of contract law: agreements between risk-neutral self interested rational utility maximizers transacting against a specific factual background. The advantage of the story in the classroom is that it asks students to adopt a perspective that might otherwise be foreign to them. It is, however, not the perspective of all contracting parties. Nor does it capture all that is going on in contractual relationships. Whether or not the theory is immoral, it is anemic.

This brings us back to the benefits of bringing legal theory into conversation with literature, theater and film. Wordsworth writes, "We murder to dissect." 14 The apothegm applies to legal theory. Private law theorists commonly seek to explain the complexity of the common law by way of a small number of simple principles, on the model of unified theories in the natural sciences. As a result, the stories they tell are often simple ones.

One way to identify the stories' assumptions and limits is to construct alternative narratives. Carol Rose's stories about the other-regarding acts that go into creating and maintaining a law of property, for example, effectively demonstrate the gaps in more familiar theory-stories about the origin of property. ${ }^{115}$

Another approach, which I have taken here, is to bring a theory into conversation with work from a different genre. Literature, theater and film often provide more morally complex and multi-layered stories. James Boyd White observes that a Platonic dialogue or play by Shakespeare

113. See, famously, Holmes, supra note 19, at 992.

114. Sweet is the lore which Nature brings;

Our meddling intellect

Mis-shapes the beauteous forms of things:-

We murder to dissect.

William Wordsworth, The Tables Turned (1798).

115. Rose, supra note 1. 
"does not work automatically, to transfer knowledge or concepts or arguments, or to serve as a set of directions, but offers the reader a complex experience of thought and judgment, an experience to which it invites and calls him but does not compel him." ${ }^{\text {"16 }}$ Film, with its mixture of word and image, is perhaps especially well suited to depicting moral complexity and multiple or shifting meanings. It is no easy thing to transpose that way of thinking into legal theory. The law often demands brighter lines, and one of the jobs of legal theory is to help draw them. But the comparison at least helps us understand the limitations of the genre, and can illuminate what a given theory captures about the world and what it does not. 
